\title{
Electroencephalographic criteria of the functional outcome prognosis in the acute period of spontaneous supratentorial intracerebral hemorrhage
}

\author{
0. A. Koziolkin $\mathbb{D}^{\mathrm{A}, \mathrm{F}}, \mathrm{A}$. A. Kuznietsov $\mathbb{1} * \mathrm{~A}-\mathrm{E}$
}

Zaporizhzhia State Medical University, Ukraine

A - research concept and design; B - collection and/or assembly of data; C - data analysis and interpretation; D - writing the article; $\mathrm{E}$ - critical revision of the article; $\mathrm{F}$ - final approval of the article

Key words: cerebral hemorrhage, electroencephalography, prognosis

Zaporozhye medical journal 2020; 22 (5), 604-610

*E-mail: titus3.05@gmail.com
The aim of this study was to define electroencephalographic predictors of unfavorable functional outcome of spontaneous supratentorial intracerebral hemorrhage (SSICH) in the acute period.

Materials and methods. Prospective, cohort and comparative study was conducted in 114 patients (mean age $67.4 \pm 0.8$ years) in the acute period of SSICH. Electroencephalography (EEG) was conducted on the $1^{\text {st }}-2^{\text {nd }}$ day of the disease. The values of relative band spectral powers of delta rhythm $(0.5-4.0 \mathrm{~Hz})$, theta $(4-8 \mathrm{~Hz})$, alpha $(8-13 \mathrm{~Hz})$, beta (13-35 Hz), theta1 (4-6 Hz), theta2 (6-8 $\mathrm{Hz})$, alpha1 $(8-10 \mathrm{~Hz})$, alpha2 $(10-13 \mathrm{~Hz})$, beta1 $(13-25 \mathrm{~Hz})$ and beta2 $(25-35 \mathrm{~Hz})$ were determined in the affected and intact hemispheres. The fronto-occipital rhythm gradient and the severity of interhemispheric rhythm asymmetry were calculated. The functional outcome of the disease in the acute period was assessed on day 21 based on the modified Rankin Scale (mRS), and the value of $\mathrm{mRS}$ score $>3$ was considered as an unfavorable functional outcome.

Results. Unfavorable functional outcome of the SSICH in the acute period was registered in 53 (46.5\%) patients. Independent association with the risk of unfavorable functional outcome of $\mathrm{SSICH}$ in the acute period was proved for the following indexes of the spectral analysis of EEG pattern in the first 2 days from the onset of the disease: the relative delta band spectral power in the affected hemisphere $(\mathrm{OR}(95 \% \mathrm{Cl})=1.18(1.11-1.25), \mathrm{P}<0.0001)$ and the fronto-occipital rhythm gradient of beta band in the affected hemisphere $(\mathrm{OR}(95 \% \mathrm{Cl})=0.0007(0.0001-0.0293), \mathrm{P}=0.0001)$. These predictors were integrated in the mathematical model for the determination of an individual risk of unfavorable functional outcome of SSICH in the acute period (AUC $(95 \% \mathrm{Cl})=0.94(0.88-0.98), \mathrm{P}<0.0001$; forecast accuracy $=87.7 \%)$.

Conclusions. Bilateral shift of EEG spectral power pattern of rhythms towards slow-wave activity of the hemisphere with the formation of interhemispheric asymmetry of delta band rhythms in the frontal areas, bilateral reduction in zonal differences of alpha band rhythms, the inversion of the fronto-occipital rhythm gradient of beta band in the affected hemisphere and the reduction in zonal differences of beta band rhythms due to beta2 band in the intact hemisphere with the formation of multidirectional interhemispheric asymmetry in the frontal and occipital parts of the brain in the first 2 days upon the onset of $\mathrm{SSICH}$ are considered as EEG criteria for unfavorable functional outcome of the disease in the acute period.

Ключові слова: внутрішньомозковий крововилив, електроенцефалографія, прогноз

Запорізький медичний журнал. 2020. T. 22, № 5(122).

C. $604-610$

\section{Електроенцефалографічні критерії прогнозу функціонального результату гострого періоду спонтанного супратенторіального внутрішньомозкового крововиливу}

\section{О. А. Козьолкін, А. А. Кузнєцов}

Мета роботи - визначити електроенцефалографічні предиктори несприятливого фрункціонального результату гострого періоду спонтанного супратенторіального внутрішньомозкового крововиливу (ССВМК).

Матеріали та методи. Здійснили проспективне, когортне, порівняльне дослідження 114 пацієнтів (середній вік - 67,4 \pm 0,9 року) в гострому періоді ССВМК на тлі консервативної терапії. Рівень неврологічного дефіциту оцінювали за National Institute of Health Stroke Scale. Електроенцефалографрічне (ЕЕГ) дослідження виконали в перші 2 доби захворювання. Окремо для ураженої та інтактної геміссрер визначали рівні відносної спектральної потужності ритмів дельта- (0,5-4,0 Гц), тета- (4-8 Гц), альфа- (8-13 Гц), бета (13-35 Гц) діапазонів, тета1- (4-6 Гц), тета2- (6-8 Гц), альфа1- (8-10 Гц), альфа2- (10-13 Гц), бета1- (13-25 Гц) і бета2- (25-35 Гц) піддіапазонів, а також лобово-потиличні градієнти, вираженість міжпівкульової асиметрії ритмів. Функціональний результат гострого періоду ССВМК оцінювали на 21 добу захворювання за модиффікованою шкалою Ренкіна (мШР), несприятливий функціональний наслідок - у разі значення >3 балів за мШР.

Результати. Несприятливий функціональний результат зареєстрували в 53 (46,5 \%) пацієнтів. Незалежна асоціація 3 ризиком несприятливого фуннціонального наслідку гострого періоду ССВМК доведена для таких показників спектрального аналізу ЕЕГ-патерну в перші 2 доби від дебюту захворювання: відносна спектральна потужність ритмів дельта-діапазону ураженої геміссрери (ВШ (95 \% ДІ) = 1,18 (1,11-1,25), p < 0,0001), лобово-потиличний градієнт ритмів бета-діапазону ураженої геміссери (ВШ $(95 \%$ ДI) = 0,0007 (0,0001-0,0293), p = 0,0001). Ці предиктори інтегровані в математичну модель для визначення індивідуального ризику несприятливого функціонального результату гострого періоду ССBMК (AUC (95\% ДІ) = 0,94 (0,88-0,98), p <0,0001; точність прогнозування = 87,7\%).

Висновки. Білатеральний зсув спектральної потужності ритмів ЕЕГ-патерну в бік повільнохвильової активності з формуванням міжпівкульової асиметрії ритмів дельта-діапазону у фронтальних відділах, білатеральна редукція зональних відмінностей ритмів альфа-діапазону, інверсія лобово-потиличного градієнта ритмів бета-діапазону в ураженій гемісфрері та редукція зональних відмінностей ритмів бета-діапазону через бета2-піддіапазон в інтактній гемісфрері з формуванням 
різноспрямованої міжпівкульової асиметрії цих ритмів у фронтальних і каудальних відділах головного мозку в перші 2 доби від дебюту ССВМК - електроенцефралографічні критерії несприятливого функціонального прогнозу результату гострого періоду захворювання.

\section{Экектроэнцефалографические критерии прогнозирования функционального исхода острого периода спонтанного супратенториального внутримозгового кровоизлияния}

\section{А. А. Козёлкин, А. А. Кузнецов}

Цель работы - определить электроэнцефалографические предикторы неблагоприятного функционального исхода острого периода спонтанного супратенториального внутримозгового кровоизлияния (ССВМК).

Материалы и методы. Проведено проспективное, когортное, сравнительное исследование 114 пациентов (средний возраст - 67,4 \pm 0,9 года) в остром периоде ССВМК на фоне консервативной терапии. Уровень неврологического дефицита оценивали по National Institute of Health Stroke Scale. Электроэнцефалографическое (ЭЭГ) исследование выполнили в первые 2 суток заболевания. Отдельно для пораженной и интактной гемисфер определяли уровни относительной спектральной мощности ритмов дельта- (0,5-4,0 Гц), тета- (4-8 Гц), альфа- (8-13 Гц), бета- (13-35 Гц) диапазонов, тета1- (4-6 Гц), тета2- (6-8 Гц), альфа1- (8-10 Гц), альфа2- (10-13 Гц), бета1- (13-25 Гц) и бета2- (25-35 Гц) поддиапазонов, а также лобно-затылочные градиенты и выраженность межполушарной асимметрии ритмов. Функциональный исход острого периода ССВМК оценивали на 21 сутки заболевания по модифицированной шкале Рэнкина (мШР), неблагоприятный функциональный исход - при значении >3 баллов по мШР

Результаты. Неблагоприятный функциональный исход зарегистрирован у 53 (46,5 \%) пациентов. Независимая ассоциация с риском неблагоприятного функционального исхода острого периода ССВМК доказана для таких показателей спектрального анализа ЭЭГ-паттерна в первые 2 суток от дебюта заболевания: относительная спектральная мощность ритмов дельта-диапазона в пораженной гемисфере (ОШ $(95 \%$ ДИ) $=1,18(1,11-1,25), p<0,0001)$, лобно-затылочный градиент ритмов бета-диапазона в пораженной гемиссрере (ОШ (95 \% ДИ) $=0,0007(0,0001-0,0293), p=0,0001)$. Эти предикторы интегрированы в математическую модель для определения индивидуального риска неблагоприятного функционального исхода острого периода ССВМК (АUС (95 \% ДИ) = 0,94 (0,88-0,98), p < 0,0001, точность прогнозирования = 87,7\%).

Выводы. Билатеральное смещение спектральной мощности ритмов ЭЭГ-паттерна в сторону медленноволновой активности с формированием межполушарной асимметрии ритмов дельта-диапазона во фронтальных отделах, билатеральная редукция зональных различий ритмов альфа-диапазона, инверсия лобно-затылочного градиента ритмов бета-диапазона в пораженной гемисфере и редукция зональных различий ритмов бета-диапазоне за счет бета2-поддиапазона в интактной гемисфере с формированием разнонаправленной межполушарной асимметрии указанных ритмов в передних и каудальных отделах головного мозга в первые 2 суток от дебюта ССВМК - ЭЭГ-критерии неблагоприятного функционального прогноза исхода острого периода заболевания.

Despite significant progress in neuroscience, acute cerebrovascular disorders (ACD) continue to occupy the leading positions amongst the causes of mortality and disability in an adult population in most countries [1,2]. Spontaneous supratentorial intracerebral hemorrhage (SSICH) with its extremely high mortality rates is the most destructive type of ACD, so the optimization of medical care issues for this group of patients is a very important problem of modern medicine $[3,4]$.

One of the most promising ways of effective treatment for patients with SSICH is the implementation of personalized medicine concept, which provides a differentiated approach to choosing optimal patient management tactics based on individual prognosis [5,6], which justifies the vitality of studies aimed at the elaboration of criteria for the prognosis of SSICH outcome in the acute period [7].

Electroencephalography (EEG) is a very informative method to objectify a functional state of the cerebral structures [8]. Numerous studies have proved the informative value of the cerebral structures functional state assessment in acute brain lesions, mostly of ischemic origin [9-11]. Several studies have been focused only on the EEG pattern in patients with $\mathrm{SSICH}$, mainly concerning aspects of the vital prognosis verification $[12,13]$. All of the aforementioned makes it important to develop the EEG criteria for the verification of the functional prognosis of the disease in the acute period.

\section{Aim}

The aim of this study was to define electroencephalographic predictors of unfavorable functional outcome of spontaneous supratentorial intracerebral hemorrhage in the acute period.

\section{Materials and methods}

In order to achieve this goal, a prospective, cohort, comparative clinical and paraclinical study was conducted among 114 patients (67 men and 47 women, mean age $67.4 \pm 0.9$ years). All the patients had a hypertensive first-ever SSICH confirmed by a clinical and neuroimaging examination. They were hospitalized to the Brain Circulation Disorders Department of the Municipal Institution "City Clinical Hospital No. 6" of the Zaporizhzhia City Council within the first 24 hours from the onset of the disease and underwent conservative therapy. A required informed consent for the study participation was signed by each patient.

If only a patient met one of the following criteria, he was excluded from the study:

1) acute cerebrovascular disorders in the anamnesis;

2) $\geq 2$ lesions of the cerebral structures;

3) confirmed aneurysm or arteriovenous malformation of cerebral vessels;

4) secondary intracerebral hemorrhage due to ischemic stroke, brain tumor, taking anticoagulants;
Киючевые слова: внутримозговое кровоизлияние, электроэнцефалография, прогноз

Запорожский медицинский журнал. 2020. T. 22, № 5(122) C. $604-610$ 
5) indications for surgical treatment based on neurosurgical examination results;

6) somatic pathology at the decompensated stage;

7) malignant tumor.

The visualization of cerebral structures was performed with the help of computed tomography scanner "Siemens Somatom Spirit" (Germany). The following features were determined: localization of the lesion, intracerebral hemorrhage volume (using the ellipsoid formula), the severity of the midline shift. The clinical and neurological examination included the assessment of neurological deficit level in accordance with the National Institute of Health Stroke Scale (NIHSS) within the dynamics of the acute period of the disease. The functional outcome of $\mathrm{SSICH}$ in the acute period was determined on the 21 st day of the disease using the modified Rankin scale, whereas score of $>3$ corresponded to unfavorable functional outcome (UFO), $\leq 3$ - favorable functional outcome.

Electroencephalographic examination was conducted within the first 48 hours from the onset of $\mathrm{SSICH}$ with the help of a 21-channel encephalograph "NeuroCom" by "XAl-Medica" (Ukraine). The electrodes were placed in accordance with the international system "10-20". Artifact-free 30-second epoch was selected in order to conduct a spectral analysis. The following features of the bioelectrical cerebral activity were determined:

1) relative spectral rhythm power (RSRP) of delta (0.5-4.0 Hz), theta $(4-8 \mathrm{~Hz})$, alpha $(8-13 \mathrm{~Hz})$, beta (13-35 $\mathrm{Hz})$, theta1 $(4-6 \mathrm{~Hz})$, theta2 $(6-8 \mathrm{~Hz})$, alpha1 $(8-10 \mathrm{~Hz})$, alpha2 $(10-13 \mathrm{~Hz})$, beta1 $(13-25 \mathrm{~Hz})$, beta2 $(25-35 \mathrm{~Hz})$ bands $(\%)$ separately for an affected hemisphere $(\mathrm{AH})$ and intact hemisphere $(\mathrm{IH})$;

2) fronto-occipital rhythm gradients (FORG) of the aforementioned bands separately for the $\mathrm{AH}$ and $\mathrm{IH}$ in accordance with the following formula: FORG (fronto-occipital rhythm gradient $)=$ (absolute spectral rhythm power of the selected band in the frontal area - absolute spectral rhythm power of the selected band in the occipital area)/ (absolute spectral rhythm power of the selected band in the frontal area + absolute spectral rhythm power of the selected band in the occipital area);

3) interhemispheric rhythm asymmetry (IHRA) of the aforementioned bands, including those taken separately for the frontal and occipital areas in accordance with the formula: interhemispheric rhythm asymmetry $($ IHRA $)=($ absolute spectral rhythm power of the selected band in the $\mathrm{AH}$ - absolute spectral rhythm power of the selected band in the $\mathrm{IH}) /($ absolute spectral rhythm power of the selected band in the $\mathrm{AH}+$ absolute spectral rhythm power of the selected band in the $\mathrm{H}$ ).

All the patients received conservative therapy in accordance with the Unified Protocol of Medical Help for Patients with SSICH, approved by the order of the Ministry of Health of Ukraine No. 275 dated 17.04.2014.

Statistical analysis of the results was carried out using Statistica 13.0 software (StatSoft Inc., USA, series number JPZ804I382130ARCN10-J) and MedCalc (version 18.2.1). The normality of the studied parameters distribution was checked with the Shapiro-Wilk criterion. As most of indexes were different from normal, descriptive statistics were presented in the form of a median and an interquartile range. The Mann-Whitney test was used for the assessment of intergroup differences. In order to define independent predictors, factors with a significant prognostic value within the univariate logistic regression analysis and the significance level $>0.05$ based on the Hosmer-Lemeshow test were gradually included to the multivariate model. Threshold values of independent predictors with the optimal ratio of sensitivity and specificity were determined based on the ROC analysis. The results with a $\mathrm{P}$ value $<0.05$ were considered as statistically significant.

\section{Results}

Hypertension was the etiological factor of SSICH in all the examined patients. The values of clinical and neuroimaging parameters in the studied cohort on the $1^{\text {st }}$ day of the disease were as follows: total NIHSS score - 11 (8; 16), intracerebral hemorrhage volume $-8.5(3.4 ; 15.5) \mathrm{ml}$, the midline shift - $1(0 ; 3) \mathrm{mm}$.

UFO in the acute period was determined in $53(46.5 \%)$ cases. It was found that patients with UFO of SSICH in the acute period had different levels of total NIHSS score on the $1^{\text {st }}$ day of the disease: $16(14 ; 18)$ versus $8(6 ; 10)$, $\mathrm{P}<0.0001)$, different lesion sizes $(12.5(8.3 ; 29.6) \mathrm{ml}$ vs. 4.3 (1.3; 9.3) $\mathrm{ml}, \mathrm{P}<0.0001)$, different midline shifts (3 (1; 4) vs. $0(0 ; 1) \mathrm{mm}, P<0.0001)$.

Based on the structural analysis of the EEG pattern in comparison with $\mathrm{SSICH}$ acute period outcome, it was determined that patients with UFO in the first 2 days from the onset of the disease had following parameters: RSRP of delta band $(45.6(33.8 ; 56.9) \%$ vs. $13.8(9.7 ; 23.2) \%$ in the $\mathrm{AH}$ and $42.9(28.9 ; 51.3) \%$ vs. $14.3(9.7 ; 24.7) \%$ in the IH, $\mathrm{P}<0.0001$ for both), RSRP of theta band (28.3 (22.9; $34.5) \%$ vs. $22.7(17.5 ; 32.4) \%$ in the $A H, P=0.0129 ; 32.8$ $(25.1 ; 42.6) \%$ vs. $22.1(15.3 ; 30.5) \%$ in the $\mathrm{H}, \mathrm{P}=0.0009)$, RSRP of alpha band $(12.9(7.4 ; 21.3) \%$ vs. 39.8 (24.1; $50.4) \%$ in the $\mathrm{AH}$ and $14.9(8.6 ; 24.5) \%$ vs. 42.1 (25.5; $47.9) \%$ in the $\mathrm{IH}, \mathrm{P}<0.0001$ for both) and RSRP of beta band $(5.5(4.0 ; 10.4) \%$ vs. $17.5(13.2 ; 20.8) \%$ in the $\mathrm{AH}$ and $6.2(3.4 ; 10.0) \%$ vs. $14.9(12.0 ; 21.0) \%, P<0.0001$ for both) (Fig. 1).

The groups of patients being compared also were different in RSRP indexes of theta1 band $(13.7(10.3 ; 18.8) \%$ vs. $10.9(8.0 ; 14.5) \%$ in the $\mathrm{AH}, \mathrm{P}=0.0071 ; 32.8(25.1 ; 42.6) \%$ and $22.1(15.3 ; 30.5) \%$ in the $\mathrm{HH}, \mathrm{P}=0.0009)$, alpha1 band $(9.7(4.8 ; 14.7) \%$ vs. $22.2(12.3 ; 34.3) \%$ in the $\mathrm{AH}$ and 9.8 $(5.1 ; 17.3) \%$ vs. $25.9(9.5 ; 35.7) \%$ in the $\mathrm{HH}, \mathrm{P}<0.0001$ for both), alfa2 band $(3.6(2.9 ; 5.7) \%$ vs. $13.5(9.3 ; 16.1) \%$ in the $\mathrm{AH}$ and $4.2(2.6 ; 6.6) \%$ vs. $12.2(7.2 ; 18.7) \%$ in the $\mathrm{IH}, \mathrm{P}<0.0001$ for both), beta1 band $(4.8(3.2 ; 7.8)$ vs. $14.6(11.3 ; 18.9) \%$ in the $\mathrm{AH}$ and $5.1(3.1 ; 8.0) \%$ vs. 12.6 $(9.7 ; 17.7) \%$ in the $\mathrm{IH}, \mathrm{P}<0.0001$ for both) and beta2 band $(1.0(0.6 ; 1.8) \%$ vs. $1.9(1.5 ; 3.0) \%$ in the $\mathrm{AH}, \mathrm{P}=0.0001$; $1.0(0.3 ; 1.5) \%$ vs. $1.6(1.2 ; 2.5)$ in the $\mathrm{H} \%, \mathrm{P}<0.0001)$.

It was determined that patients with UFO of SSICH in the first 2 days of the disease had different inversions of the negative fronto-occipital gradient of the total absolute spectral rhythm power in the frontal areas of the $\mathrm{AH}$ in comparison with the occipital areas $(0.100(0.006 ; 0.211)$ vs. $-0.072(-0.231 ; 0.084), P<0.0001$ for both). The detected differences in the $\mathrm{AH}$ were due to higher fronto-occipital rhythm gradient of alpha band $(-0.039(-0.151 ; 0.130)$ vs. $-0.232(-0.491 ; 0.082), P=0.0042)$ due to alpha1 

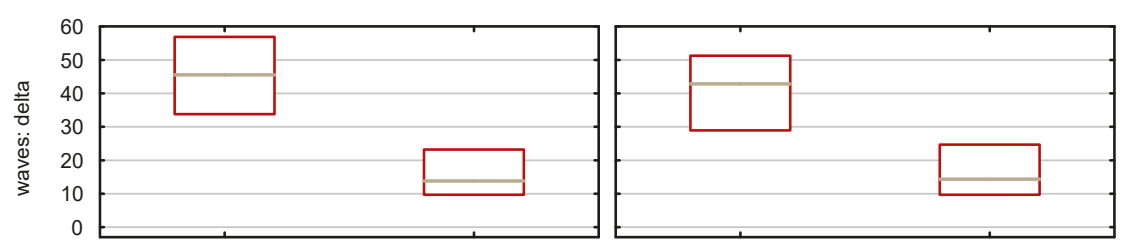

Fig. 1. RSRP levels

in the affected and intact

hemispheres in the first

48 hours from the onset

of SSICH in comparison

with the functional outcome

in the acute period of

the disease.
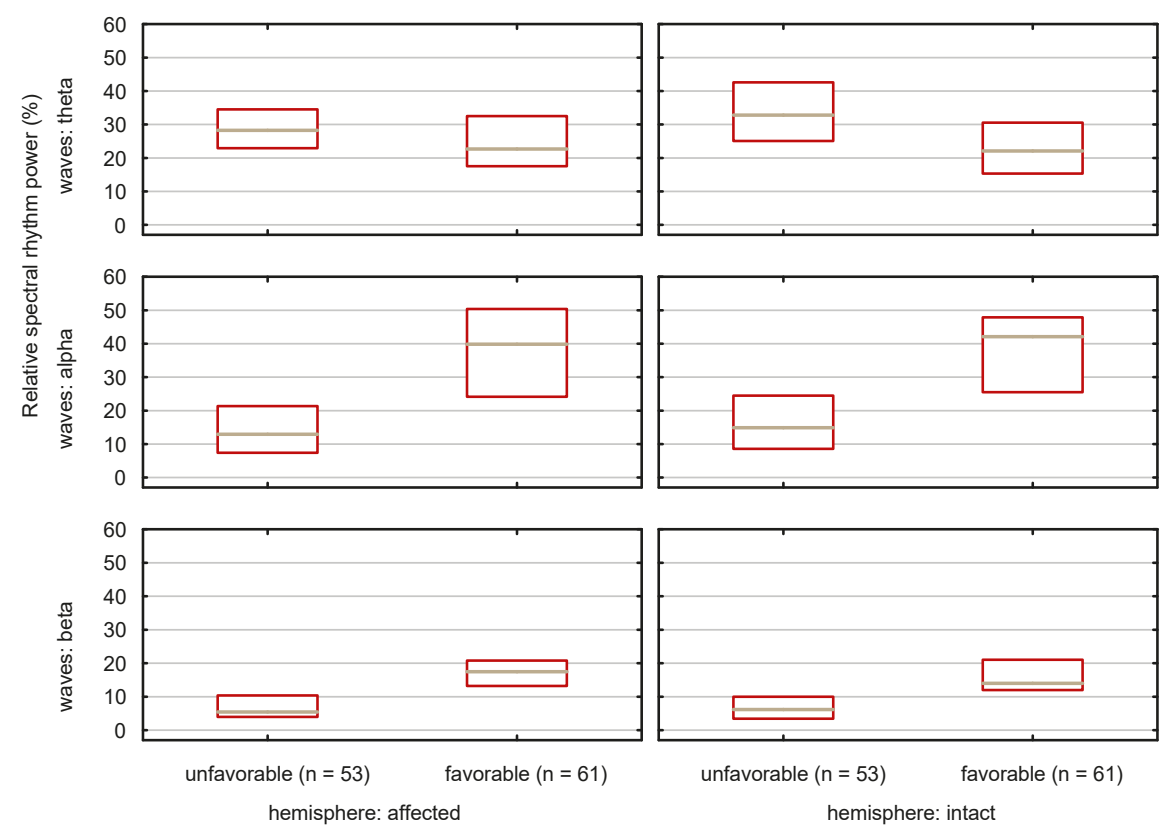

$\mathrm{SSICH}$ acute period functional outcome

- Median

$\square 25-75 \%$
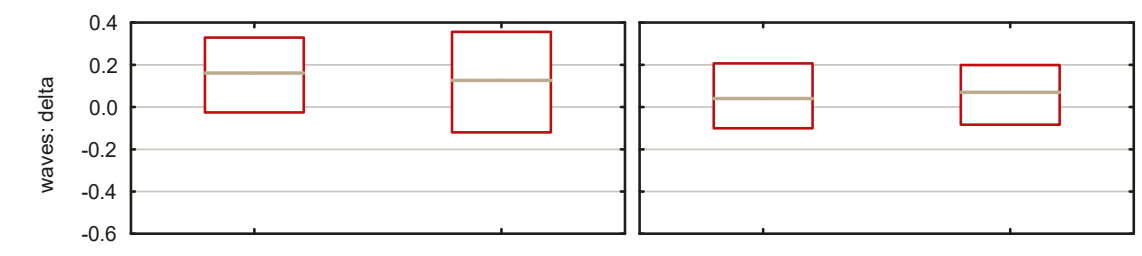

Fig. 2. Fronto-occipital rhythm gradient levels

in the $\mathrm{AH}$ and $\mathrm{IH}$ in the first 2 days of SSICH in

comparison with functional

outcome of the disease

in the acute period.
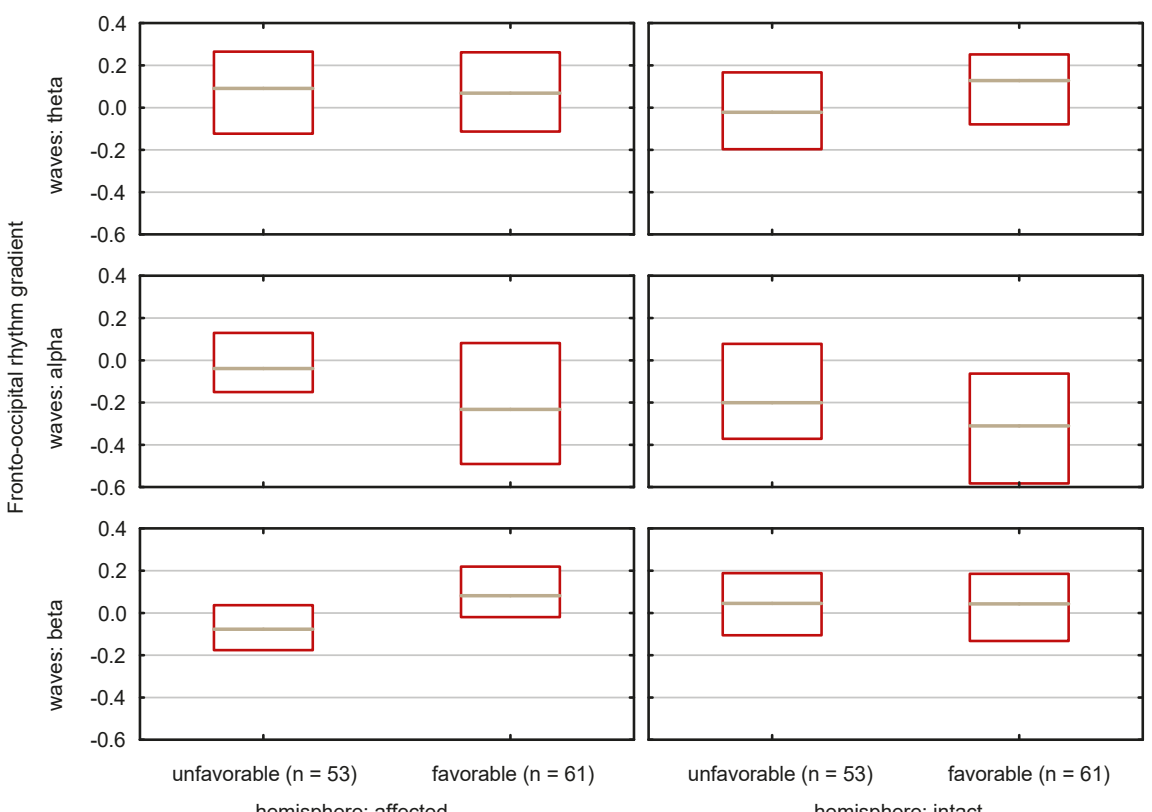

hemisphere: affected

hemisphere: intact 
Table 1. RSRP indexes of EEG pattern in the first 2 days of $\mathrm{SSICH}$, associated with the risk of unfavorable functional outcome in the acute period of the disease (based on the results of univariate logistic regression analysis)

\begin{tabular}{l|l|l|l|}
\hline Parameters & OR & $95 \%$ CI & P \\
\hline RSRP of delta band in the AH & 1.13 & $1.08-1.17$ & $<0.0001$ \\
\hline RSRP of alpha1 band in the AH & 0.89 & $0.85-0.93$ & $<0.0001$ \\
\hline RSRP of alpha band in the AH & 0.89 & $0.85-0.93$ & $<0.0001$ \\
\hline RSRP of alpha1 band in the IH & 0.92 & $0.89-0.96$ & $<0.0001$ \\
\hline FORG of alpha1 band in the AH & 5.91 & $2.00-17.49$ & 0.0013 \\
\hline FORG of alpha band in the AH & 5.85 & $1.77-19.38$ & 0.0038 \\
\hline FORG of beta1 band in the AH & 0.04 & $0.001-0.31$ & 0.0023 \\
\hline FORG of beta2 band in the AH & 0.05 & $0.01-0.21$ & 0.0001 \\
\hline FORG of beta band in the AH & 0.02 & $0.004-0.20$ & 0.0007 \\
\hline FORG of theta2 band in the IH & 0.13 & $0.04-0.45$ & 0.0014 \\
\hline FORG of alpha2 band in the IH & 8.21 & $2.09-32.33$ & 0.0026 \\
\hline FORG of alpha band in the IH & 4.15 & $1.22-14.11$ & 0.0227 \\
\hline FORG of beta2 band in the IH & 0.11 & $0.03-0.43$ & 0.0013 \\
\hline IHRA of delta band frontal area & 9.20 & $1.94-43.53$ & 0.0052 \\
\hline IHRA of alpha2 band in the frontal area & 0.17 & $0.04-0.74$ & 0.0184 \\
\hline IHRA of beta1 band in the frontal area & 0.01 & $0.001-0.22$ & 0.0023 \\
\hline IHRA of beta band in the frontal area & 0.02 & $0.002-0.41$ & 0.0100 \\
\hline IHRA of theta2 band in the occipital area & 0.14 & $0.04-0.49$ & 0.0020 \\
\hline IHRA of alpha1 band in the occipital area & 0.28 & $0.10-0.78$ & 0.0154 \\
\hline IHRA of beta1 band in the occipital area & 12.58 & $1.59-99.41$ & 0.0163 \\
\hline IHRA of beta band in the occipital area & 19.19 & $2.07-177.74$ & 0.0093 \\
\hline
\end{tabular}

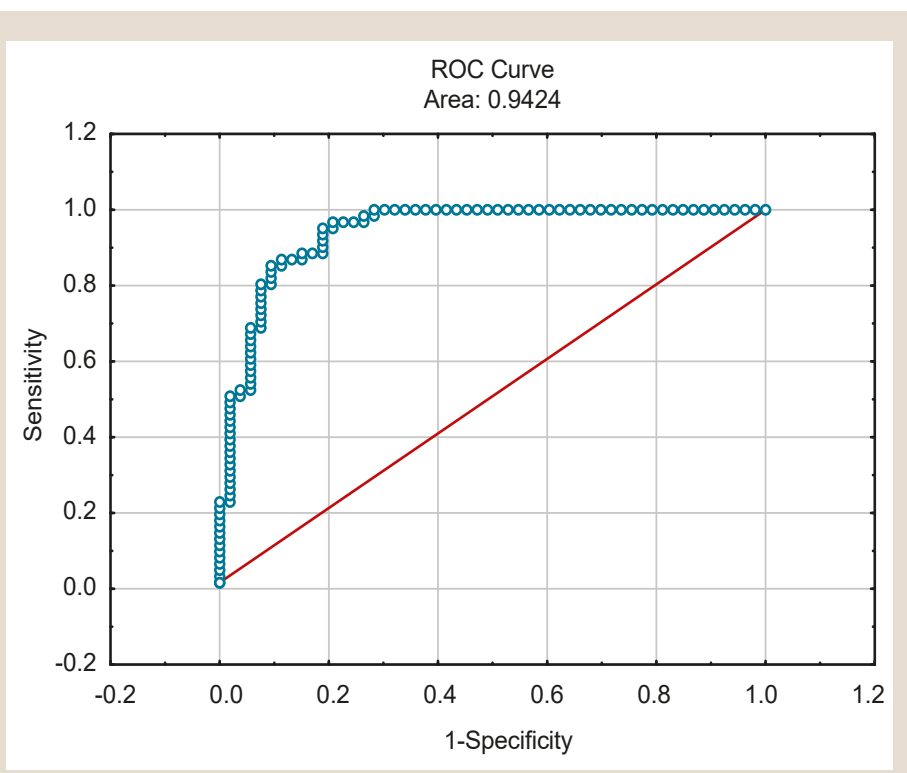

Fig. 3. ROC-curve of the developed mathematical model for the prognosis of the unfavorable functional outcome of SSICH in the acute period.

band $(-0.002(-0.210 ; 0.236)$ vs. $-0.266(-0.558 ; 0.051)$, $\mathrm{P}=0.0012)$ and beta band $(-0.077(-0.176 ; 0.037)$ vs. $0.082(-0.020 ; 0.220), P=0.0001)$ due to beta1 band $(-0.056$ $(-0.168 ; 0.041)$ vs. $0.073(-0.035 ; 0.205), P=0.0005)$ and beta2 band $(-0.070(-0.285 ; 0.259)$ vs. $0.230(0.071 ; 0.339)$, $\mathrm{P}<0.0001)$. The differences in the fronto-occipital rhythm gradient in the $\mathrm{IH}$ were detected in theta band $(-0.022$ $(-0.197 ; 0.167)$ vs. $0.128(-0.079 ; 0.252), P=0.0416)$ by means of theta2 band $(-0.180(-0.432 ; 0.053)$ vs. 0.045 $(-0.135 ; 0.213), P=0.0005)$, alpha band $(-0.201(-0.371$; $0.078)$ vs. $-0.310(-0.582 ;-0.063), P=0.0194)$ by means of alpha2 band $(-0.078(-0.289 ; 0.057)$ vs. $-0.289(-0.489$;
$-0.150), P=0.0009)$, beta2 band $(-0.036(-0.150 ; 0.206)$ vs. 0.281 (0.101; 0.416), $P=0.0005$ ) (Fig. 2).

Based on the analysis of the interhemispheric organization of EEG pattern characteristics, it was determined that patients with UFO in the acute period of SSICH diring the first 2 days of the disease onset had greater interhemispheric asymmetry in the frontal areas by means of delta band rhythms $(0.169(0.020 ; 0.318)$ vs. $0.072(-0.166$; $0.161), P=0.0030)$ and beta1 band $(-0.052(-0.222$; $0.030)$ vs. $-0.015(-0.105 ; 0.110), P=0.0046)$ combined with smoothed interhemispheric rhythm asymmetry of alpha2 band $(0.008(-0.175 ; 0.193)$ vs. $0.081(-0.029$; $0.234), P=0.0471)$ by means of alpha2 band $(-0.051$ $(-0.339 ; 0.134)$ vs. $0.061(-0.111 ; 0.214), P=0.0266)$. As for the occipital areas, interhemispheric rhythm asymmetry showed negative indexes of theta2 band $(-0.093(-0.423$; $0.139)$ vs. $0.063(-0.132 ; 0.233), P=0.0042)$ and alpha1 band $(-0.160(-0.461 ;-0.009)$ vs. $0.010(-0.252 ; 0.229)$, $P=0.0111)$, whereas beta band and beta2 band had positive interhemispheric rhythm asymmetry: $0.044(-0.082 ; 0.151)$ vs $-0.055(-0.193 ; 0.055)(P=0.0032)$ and $0.048(-0.101$; $0.137)$ vs. $-0.067(-0.216 ; 0.072)(P=0.0102)$, respectively. Intergroup differences in interhemispheric asymmetry of the total absolute spectral power were detected only for alpha band rhythms $(-0.128(-0.280 ; 0.073)$ vs. -0.041 $(-0.180 ; 0.161), P=0.0484)$.

The most significant indexes of RSRP, FORG and IHRA of EEG pattern were determined based on the univariate logistic regression analysis. All of these were associated with the risk of UFO in the acute period of SSICH (Table 1).

The use of multivariate logistic regression analysis allowed to determine that the following indexes were associated with SSICH outcome in the acute period amongst the aforementioned spectral analysis indexes of the brain bioelectrical activity: RSRP of delta band in the AH (OR $(95 \% \mathrm{Cl})=1.18(1.11-1.25), \mathrm{P}<0.0001)$ and FORG of beta band in the $\mathrm{AH}(\mathrm{OR}(95 \% \mathrm{Cl})=0.0007(0.0001-0.0293)$, $P=0.0001)$. These indexes maintained a statistically significant relation with the functional outcome in the acute period of SSICH in case of the following clinical and neuroimaging criteria inclusion to the list of potential predictors: total NIHSS score, intracerebral hemorrhage volume, severity of midline shift.

A mathematical model for the determination of the individual risk of UFO in the acute period of SSICH was developed on the basis of the brain bioelectrical activity spectral analysis results in the first 2 days from the disease onset. It is represented by the following binary logistic regression equation:

$\beta=-4.67+0.16 \times$ Pred1 $-7.24 \times$ Pred2, where

$-6.55-\beta_{0}$ (intercept);

Pred1 - RSRP of delta band in the $\mathrm{AH}$;

Pred2 - FORG of beta band in the AH.

On the basis of the ROC-analysis, it was determined that the value $\beta>-0.2$ was the integral electroencephalographic predictor of UFO in the acute period of $\mathrm{SSICH}$ (sensitivity $=83.0 \%$; specificity $=93.4 \%$; AUC $(95 \%$ $\mathrm{Cl})=0.94$ (0.88-0.98), $\mathrm{P}<0.0001$ ) (Fig. 3).

The proportion of correctly classified observations using this model constituted $87.7 \%$ (the level of statistical significance according to the Hosmer-Lemeshow test $\mathrm{P}=0.8377$ ). 


\section{Discussion}

The comparative analysis of the brain bioelectrical activity spectral parameters showed a bilateral predomination of a slow-wave activity (mostly delta) in the EEG pattern in patients with UFO of SSICH in the acute period in the first 2 days upon the onset of the disease. The RSRP values of delta band in this group of patients were 3.0-3.3 times higher. Lower RSRP levels of alpha band (2.8-3.1 times) and beta band (2.3-3.2 times) were reciprocal in both hemispheres. The obtained data are consistent with the results of studies on the prognostic value of spectral analysis of brain bioelectrical activity in patients with acute brain lesions of ischemic origin, which determined the relation between the spectral power shift towards slow-wave activity and the worse outcome of the disease $[10,11]$.

The specific features of the interhemispheric organization of the EEG pattern in comparison with the functional outcome of SSICH in the acute period were also determined. Bilateral reduction in FORG of alpha band combined with the inversion of FORG of beta band in the $\mathrm{AH}$ and beta2 band in the IG was typical for the subcohort of patients with unfavorable functional prognosis of $\mathrm{SSICH}$ in the acute period in the first 2 days upon the onset of the disease.

Thus, the reduction in FORG of alpha band showed the smoothing of differences between the frontal and occipital areas due to the levels of absolute spectral power of these rhythms. The obtained data are consistent with the results of a study conducted by $\mathrm{M}$. Purandare et al. (2018) [13], which demonstrated the informative value of the reduction in the fronto-occipital gradient of rhythms as an electroencephalographic predictor of intracerebral hemorrhage unfavorable outcomes. In our opinion, the detected changes in FORG of alpha band in the $\mathrm{AH}$ and $\mathrm{IH}$ have different origins. Thus, the reduction in FORG of alpha band in the $\mathrm{AH}$ reflects ipsilateral depression of the absolute spectral rhythm power in the occipital areas due to focal lesions of specific brain systems; whereas the reduction in FORG of alpha band in the $\mathrm{IH}$ is due to the elevation of the absolute spectral rhythm power in the frontal area. The heterogeneous genesis of changes in FORG of alpha band in the $\mathrm{AH}$ and $\mathrm{IH}$ was also confirmed by the fact that the reduction in FORG of alpha1 band was detected in the $\mathrm{AH}$, whereas the $\mathrm{IH}$ showed the reduction in FORG of alpha2 band. Statistically significant intergroup differences were also identified in RSRP of alpha2 band in the frontal area. The FORG inversion of beta band in the $A H$ and FORG of beta2 band in the AH showed a more pronounced decrease in the absolute spectral power of the abovementioned rhythms in the frontal areas of both hemispheres in comparison with the occipital areas.

The detailed analysis of intergroup differences between IHA indexes in the frontal and occipital areas of the brain allowed to specify the changes in the interhemispheric EEG pattern organization and to find the following peculiarities of IHA, associated with the high risk of UFO in the acute period of SSICH:

1) greater IHRA of delta band in the frontal areas due to the aforementioned activity prevalence in the $\mathrm{AH}$ in comparison with the IH as for the absolute spectral power level;

2) smooth IHRA of alpha2 band in the frontal areas due to the aforementioned activity prevalence in the $\mathrm{AH}$ in comparison with the $\mathrm{IH}$ as for the absolute spectral power level;
3) negative IHRA of theta2 band in the occipital areas due to the aforementioned activity prevalence in the $\mathrm{AH}$ in comparison with the $\mathrm{IH}$ as for the absolute spectral power level;

4) negative IHRA of alpha1 band in the occipital areas due to the aforementioned activity prevalence in the $\mathrm{AH}$ in comparison with the $\mathrm{IH}$ as for the absolute spectral power level;

5) IHRA of beta band by means of beta2 band in the occipital areas due to the aforementioned activity prevalence in the $\mathrm{AH}$ in comparison with the $\mathrm{IH}$ as for the absolute spectral power level.

The detected significant differences between the studied groups as for clinical and neuroimaging parameters allow us to consider the abovementioned changes in the EEG pattern to be neurophysiological markers of the severity in focal lesions of the cerebral structures. The study provided the diagnostic value of FORG and IHRA of different bands (in the frontal and occipital areas) in order to determine the functional prognosis of SSICH in the acute period. Namely, unfavorable prognosis was illustrated by the bilateral reduction in zonal differences in alpha rhythm range (due to alpha1 band in the $\mathrm{AH}$, alpha2 band in the $\mathrm{IH}$ ), the FORG inversion of beta range in the $\mathrm{AH}$, and the reduction in zonal rhythm differences in beta2 band in the $\mathrm{H}$ with the formation of multidirectional interhemispheric asymmetry found in the frontal and occipital areas of the brain.

Based on the univariate logistic regression analysis, the most informative indicators of RSRP, FORG and IHRA were determined to predict the functional outcome of the acute period in SSICH. The multivariate logistic regression analysis allowed to verify independent electroencephalographic predictors (RSRP of delta band, FORG of beta band) and to integrate them into the mathematical model enabling clinicians to identify patients with increased risk of UFO in the acute period of SSICH with an accuracy of $87.7 \%$. The analysis of the electroencephalographic predictor coefficients, included in the mathematical model, led to the identification of a link between these indicators and the risk of lethal outcome. Thus, the coefficient of RSRP of delta band in the $\mathrm{AH}$ had a positive value, while the coefficient and FORG of beta band in the AH had a negative value. The abovementioned confirms that UFO of SSICH in the acute period was associated with high RSRP indexes of delta band in the $\mathrm{AH}$ and low FORG indexes (including negative) of beta band in the $\mathrm{AH}$.

The value of AUC of the developed mathematical model constituted $0.94(P<0.0001)$ indicating a high forecast accuracy (based on the assessment with the help of the scale of M. H. Zweig, G. Campbell (1993) [14]). It also has proved the viability if its use in patients with $\mathrm{SSICH}$ within the complex of diagnostic procedures for the functional prognosis verification of the acute period outcome in $\mathrm{SSICH}$ and as the basis for making decisions for further medical treatment issues.

\section{Conclusions}

1. Bilateral shift of EEG spectral power pattern of rhythms towards the slow-wave activity with the formation of interhemispheric asymmetry of delta band rhythms in the frontal areas, bilateral reduction in zonal differences 
of alpha band rhythms (by means of alpha2 band, alpha1 band), the inversion of fronto-occipital rhythm gradient of beta band in the affected hemisphere and the reduction in zonal differences in beta band rhythms due to beta2 band in the intact hemisphere with the formation of multidirectional interhemispheric asymmetry in the frontal and occipital parts of the brain in the first 2 days upon the onset of SSICH are considered as criteria for the unfavorable functional outcome in the acute period of the disease.

2. Independent association with the risk of unfavorable functional outcome of SSICH in the acute period was proved for the following indexes of the spectral analysis of EEG pattern in the first 2 days from the disease onset: the relative spectral rhythm power of delta band in the affected hemisphere $(\mathrm{OR}(95 \% \mathrm{Cl})=1.18(1.11-1.25), \mathrm{P}<0.0001)$ and fronto-occipital rhythm gradient of beta band in the affected hemisphere $(\mathrm{OR}(95 \% \mathrm{Cl})=0.0007(0.0001-0.0293)$, $P=0.0001$ ).

3. The mathematical model for the determination of an individual risk of unfavorable functional outcome of $\mathrm{SSICH}$ in the acute period was developed. It takes into consideration the most informative indexes of a spectral analysis of the brain bioelectrical activity in the first 2 days upon the onset of the disease (AUC $(95 \% \mathrm{Cl})=0.94(0.88-0.98)$, $\mathrm{P}<0.0001$; forecast accuracy $=87.7 \%$ ).

The perspective for the further studies is to increase the forecast accuracy for the short-term functional prognosis in patients with SSICH based on the assessment of EEG pattern reorganization in the acute period of the disease.

\section{Funding}

The study is funded as a part of scientific research work at Zaporizhzhia State Medical University "Improving diagnosis and treatment of cerebral circulation disorders at different stages of the disease", number of state registration $0118 \mathrm{U} 007145$ (2018-2023).

Conflicts of interest: authors have no conflict of interest to declare. Конфлікт інтересів: віАсутній.

Нааійшла Ао реАакції / Received: 17.07.2020

Після Аоопрацювання / Revised: 10.08.2020

Прийнято АО Аруку / Accepted: 12.08.2020

Information about authors:

Koziolkin O. A., MD, PhD, DSc, Professor, Head of the Department of Nervous Diseases, Zaporizhzhia State Medical University, Ukraine. ORCID ID: 0000-0001-9878-5798

Kuznietsov A. A., MD, PhD, Associate Professor of the Department of Nervous Diseases, Zaporizhzhia State Medical University, Ukraine. ORCID ID: 0000-0002-6118-9682

\section{Відомості про авторів:}

Козьолкін О. А., А-р меА. наук, професор, зав. каф. нервових хвороб, Запорізький державний меАичний університет, Україна. Кузнєцов А. А., канА. меА. наук, Аоцент каф. нервових хвороб, Запорізький Аержавний медичний університет, Україна.

\section{Сведения об авторах:}

Козёлкин А. А., А-р меА. наук, профессор, зав. каф. нервных болезней, Запорожский государственный меАицинский университет, Украина.

Кузнецов А. А., канА. меА. наук, Аоцент каф. нервных болезней, Запорожский государственный меАицинский университет, Украина.

\section{References}

[1] Katan, M., \& Luft, A. (2018). Global Burden of Stroke. Seminars in Neurology, 38(2), 208-211. https://doi.org/10.1055/s-0038-1649503

[2] An, S. J., Kim, T. J., \& Yoon, B. W. (2017). Epidemiology, Risk Factors, and Clinical Features of Intracerebral Hemorrhage: An Update. Journal of Stroke, 19(1), 3-10. https://doi.org/10.5853/ios.2016.00864

[3] Alerhand, S., \& Lay, C. (2017). Spontaneous Intracerebral Hemorrhage. Emergency Medicine Clinics of North America, 35(4), 825-845. https:/l doi.org/10.1016/i.emc.2017.07.002

[4] Ziai, W. C., \& Carhuapoma, J. R. (2018). Intracerebral Hemorrhage. Continuum, 24(6), 1603-1622. https://doi.org/10.1212 CON.0000000000000672

[5] Steiner, T., Al-Shahi Salman, R., Beer, R., Christensen, H., Cordonnier, C., Csiba, L., Forsting, M., Harnof, S., Klijn, C. J., Krieger, D., Mendelow, A. D., Molina, C., Montaner, J., Overgaard, K., Petersson, J., Roine, R. O., Schmutzhard, E., Schwerdtfeger, K., Stapf, C., Tatlisumak, T., ... European Stroke Organisation. (2014). European Stroke Organisation (ESO) Guidelines for the Management of Spontaneous Intracerebral Hemorrhage. International Journal of Stroke, 9(7), 840855. https://doi.org/10.1111/ijs.12309

[6] Gregório, T., Pipa, S., Cavaleiro, P., Atanásio, G., Albuquerque, I. Chaves, P. C., \& Azevedo, L. (2018). Prognostic models for intracerebral hemorrhage: systematic review and meta-analysis. BMC Medical Research Methodology, 18(1), Article 145. https://doi.org/10.1186 s12874-018-0613-8

[7] Safatli, D. A., Günther, A., Schlattmann, P., Schwarz, F., Kalff, R, \& Ewald, C. (2016). Predictors of 30-day mortality in patients with spontaneous primary intracerebral hemorrhage. Surgical Neurology International, 7(Suppl. 18), S510-S517. https://doi.org/10.4103/21527806.187493

[8] Stojanović, B., \& Djurasić, L. (2013). Predictive importance of Index of Asymmetry in recovery following stroke. Acta Chirurgica lugoslavica, 60(1), 101-104. https://doi.org/10.2298/aci1301101s

[9] Xin, X., Chang, J., Gao, Y., \& Shi, Y. (2017). Correlation Between the Revised Brain Symmetry Index, an EEG Feature Index, and Short-term Prognosis in Acute Ischemic Stroke. Journal of Clinical Neurophysiology, 34(2), 162-167. https://doi.org/10.1097/WNP.0000000000000341

[10] Sheorajpanday, R. V., Nagels, G., Weeren, A. J., van Putten, M. J., \& De Deyn, P. P. (2011). Quantitative EEG in ischemic stroke: Correlation with functional status after 6 months. Clinical Neurophysiology, 122(5), 874-883. https://doi.org/10.1016/i.clinph.2010.07.028

[11] Wolf, M. E., Ebert, A. D., \& Chatzikonstantinou, A. (2017). The use of routine EEG in acute ischemic stroke patients without seizures: generalized but not focal EEG pathology is associated with clinical deterioration. International Journal of Neuroscience, 127(5), 421-426. https://doi.org/10.1080/00207454.2016.1189913

[12] Chen, Y., Xu, W., Wang, L., Yin, X., Cao, J., Deng, F., Xing, Y., \& Feng, J. (2018). Transcranial Doppler combined with quantitative EEG brain function monitoring and outcome prediction in patients with severe acute intracerebral hemorrhage. Critical Care, 22(1), Article 36. https:/l doi.org/10.1186/s13054-018-1951-y

[13] Purandare, M., Ehlert, A. N., Vaitkevicius, H., Dworetzky, B. A., \& Lee, J. W. (2018). The role of CEEG as a predictor of patient outcome and survival in patients with intraparenchymal hemorrhages. Seizure, 61, 122-127. https://doi.org/10.1016/i.seizure.2018.08.014

[14] Zweig, M. H., \& Campbell, G. (1993). Receiver-Operating Characteristic (ROC) Plots: a Fundamental Evaluation Tool in Clinical Medicine. Clinical Chemistry, 39(4), 561-577. 